\title{
Assessment of soil sanitary parameters in cedar plantations
}

\author{
Svetlana Khamitova ${ }^{1}$, Yuri Avdeev ${ }^{1, *}$, Ilfir Galiullin ${ }^{2}$, Alexandra Popova ${ }^{1}$, and Victor Lukashevich ${ }^{3}$ \\ ${ }^{1}$ Vologda State University, 160000 Vologda, Russia \\ ${ }^{2}$ Kazan State Agrarian University, 420015 Kazan, Russia \\ ${ }^{3}$ Petrozavodsk State University, 185910 Petrozavodsk, Russia
}

\begin{abstract}
The paper presents the results of the study of sanitary and microbiological parameters of soils in cedar plantations on the example of the Vologda Region of Russia. The statistical description of cedar plantations showed that both urban and Siberian cedar plantations in urban environments and beyond are characterized by good growth. The results of the sanitary assessment of cedar plantations showed that the largest part of them is classified as the second class. The evaluation of the gross heavy metal content of soil samples showed that the numerical values of test elements (copper, zinc, lead, cadmium, nickel, chromium, arsenic, mercury) did not exceed MPC. The analysis for the content of heavy metals in soil of cedar groves and nurseries is one of the ways to achieve sustainable development and functioning of the studied objects, to grow healthy cedar plantations. It is aimed at improving the environment of the Gryazovetskaya district of Vologda Region, as well as at modeling and development of environmental measures. On the basis of sanitary and microbiological assessment in the examined cedar groves it is recommended to carry out selective forest protection measures, to clean debris, as well as to conduct laboratory studies in order to determine soil toxicity affecting growth and development of cedar plantations.
\end{abstract}

\section{Introduction}

Urban environment is the system of natural, anthropogenic (technogenic) and socio-economic conditions that may have a considerable impact on city residents [1-3]. The quality indicators of urban environment are indicators of sustainable development of the city, creation of a green urbanized environment, which is extremely popular these days $[4,5]$.

The aim if this work is to study the soil conditions of Chagrinskaya and Gryazovetskaya cedar groves and a nursery near the Zhernokovo village - this is an important contribution to the improvement of the environment in Gryazovets district of Vologda Region.

Cedar forests in the objects under study bear important recreational, sanitary and reproductive value. In order to grow healthy cedar plantations, it is necessary to take into account a number of factors. One of the most important of them is soil cover, namely, its microflora, microbiological indicators, content of toxic elements associated with rhizospheric part of an alpine stone pine.

The purpose of the study is to analyze microbiological and toxic parameters, as well as soil colonization with microorganisms in cedar plantations of Vologda Region.

\section{Materials and methods}

Cedar groves and a nursery in the Gryazovetsk district of Vologda Region (in Gryazovets and outside the city - in
Chagrino village and near Zhernokovo village) were taken as objects of the study.

Their location is shown schematically on the area diagram (Figure 1).

In the cedar groves of the Gryazovets district there is a Siberian cedar pine - a valuable nut-bearing tree adapted to the climatic conditions of the area. The groves bear cultural, historical, recreational and aesthetic value.

Microbiological study, namely the detection and quantification of microorganisms, the assessment of the level of enzymatic activity, analysis for the content of heavy metals in the soil of cedar groves and a nursery, are topical directions of modern times, which are necessary in order to maintain sanitary and hygienic characteristics of groves, preserve valuable wood rocks, model and develop environmental measures [2,6].

The first studied object is the Chagrinskaya cedar grove being a botanical nature sanctuary of regional value of 29.01.1963. It is located in Vologda Region, Gryazovetsky municipal district (MO Komyanskoye, Chagrino village) and occupies the area of 3.7 hectares.

Chagrinskaya Grove is located $36 \mathrm{~km}$ from Vologda and $23 \mathrm{~km}$ from Gryazovets at the junction of Vologda Highland and Prisuchonskaua Lowland, which has the shape of an elongated quadrangle.

The grove with the bedding of oak, maple, smallleaved lime, ash and hazel, as well as common pine and alpine stone pine was founded in the Chagrinskaya Estate in the second half of the $19^{\text {th }}$ century (planted by landlord N.A. Petrov in 1900-1901 near Shipyakovo

Corresponding author: avdeevyur@yandex.ru 
village). The grove was laid by five- to ten-year-old cedar trees, and the wild tree were planted at a distance of ten by ten meters.

Today in the park there are 28 rows of old plants, in each of which from 4 to 22 trees up to 12 meters high have been preserved. The most powerful trees with a diameter of 60 to $80 \mathrm{~cm}$ are located in the middle part of a tree belt on a low hill. In the early 1990s, young 15-, 20-year-old cedar pines, small-leaved limes and fir trees were planted.

To date, 133 cedar trees with strong trunks, the average height of which is $19.5 \mathrm{~m}$, have survived in the grove.

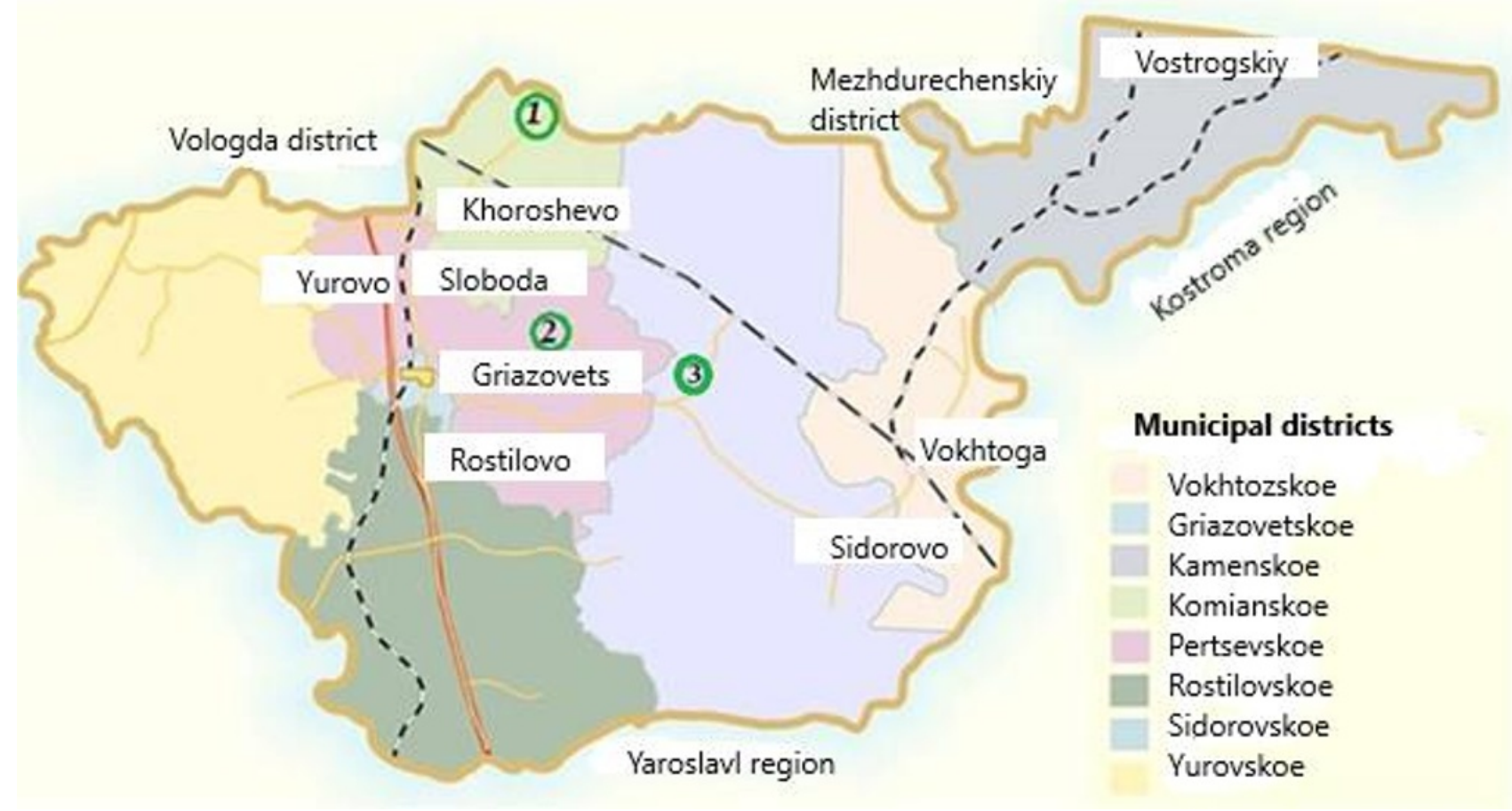

Fig. 1. Gryazovets district: 1 - Chagrinskaya cedar grove; 2 - cedar grove in Gryazovets; 3 - cedar nursery near Zhernokovo village

The second research object is the Gryazovetskaya cedar grove, which was laid down in 1966. It is located $47 \mathrm{~km}$ from Vologda. The area of the grove is one hectare.

About 300 six-year-old cedar seedlings are planted in the grove, which are initially grown in greenhouse conditions and then in the open ground. Previously, the square was tilled, cultivated and plowed.

The plants were bedded out at a distance of four by four meters. For each seedling, a seat was prepared and filled with decomposed manure, composts mixed with sand and mineral fertilizers. The territory had trenches along the perimeter.

In the early years, the students of the local technical school ensured agrotechnical tending of trees. In the center of the grove the date of creation of this plantation is monumentalized in the form of a commemorative sign.

Currently, the grove is represented by 78 cedars of different vital condition with an average trunk diameter from 20 to $30 \mathrm{~cm}$.

The third research object was a cedar nursery near Zhernokovo village, which is $71 \mathrm{~km}$ from Vologda and $23 \mathrm{~km}$ from Gryazovets. It is shown in Figure 2.4. The plantation was formed in 1977 by seedlings of four to five years of age that were originally grown from seeds and harvested in Chagrinskaya Grove.
The area of planting is 1.2 hectares. To date, about 500 cedar trees grow in the nursery. There is also a commemorative sign with the date of creation of this plantation.

Methods of forest mensuration were used in the presentation of the material, the inventory characteristic of cedar plantations in the studied objects was made according to indicators describing qualitative and quantitative characteristics: age, number of trees in a grove, average height of a trunk, average diameter of a trunk, average diameter of the crown.

The sanitary condition of trees in cedar groves and in the nursery was split into classes of sanitary condition according to a number of features: loss of needles, loss of green color of needles, condition of the top, condition of the tree trunk [7,8].

Soil samples were taken during spring, summer and autumn 2018 for toxicity studies and microbiological analyses. Laboratory and toxicologic testing methods were used to determine the toxicity of soil samples taken in cedar plantations under study. The analysis was carried out at the Vologodsky Center of Agrochemical Service (Molochnoye village) on atomic absorption spectrophotometer C-115 M1.

The degree of chemical contamination of the soil in cedar groves and the nursery was assessed by sanitary and hygienic rating of the content of heavy metals $(\mathrm{Cu}$, $\mathrm{Zn}, \mathrm{Pb}, \mathrm{Cd}, \mathrm{Ni}, \mathrm{Cr}, \mathrm{As}, \mathrm{Hg}$ ) in the soil cover by 
comparing the actual determined concentration of elements with the maximum permissible concentration (MPC) $[6,9,10]$.

The evaluation of invertase activity is based on the accounting of reducing sugars formed during sucrose splitting via the colorimetric method.

\section{Results and discussion}

The mensurational description of cedar plantations in the objects of the study was carried out: Chagrino, Gryazovets and Zhernokovo. Indicators describing qualitative and quantitative characteristics were assessed: age, number of trees in the grove, average height of a trunk, average diameter of a trunk, average diameter of the crown. The results are shown in Table 1.

Table 1. Characteristic of Siberian cedar in groves of Gryazovets district

\begin{tabular}{|l|c|c|c|c|c|}
\hline \multirow{2}{*}{ Research object } & \multicolumn{5}{|c|}{ Taxational characteristic } \\
\cline { 2 - 6 } & Age, years & $\begin{array}{c}\text { Number of trees } \\
\text { in a grove, pcs. }\end{array}$ & $\begin{array}{c}\text { Average height of } \\
\text { a trunk, } \mathrm{m}\end{array}$ & $\begin{array}{c}\text { Average diameter } \\
\text { of a trunk, cm }\end{array}$ & $\begin{array}{c}\text { Average } \\
\text { diameter of the } \\
\text { crown, } \mathrm{m}\end{array}$ \\
\hline Chagrinskaya Grove & 117 & 133 & 19.5 & 62.1 & 6.9 \\
\hline Gryazovetskaya Grove & 52 & 78 & 12.4 & 25.1 & 3.7 \\
\hline Zhernokovo nursery & 41 & 500 & 12.3 & 25.1 & 4.1 \\
\hline
\end{tabular}

Both park plantations of Siberian cedar and near settlements in the objects under study are characterized by good growth. Good lighting of crowns due to thin planting contributed to their development and increased trunk growth in diameter.

To date, 133 cedar trees with strong trunks have survived on 3.7 hectares of the Chagrinskaya Grove. Their average height is $19.5 \mathrm{~m}$. In the Gryazovetskaya Grove, the area of which reaches one hectare, 78 cedar trees with an average trunk height of $12.4 \mathrm{~m}$, in the nursery - area 1.2 hectares with about 500 cedars with an average height of $12.3 \mathrm{~m}$.

By the age of 117, the Chagrinskaya Grove has an average trunk diameter of $62.1 \mathrm{~cm}$ and the average width of the crown $-6.9 \mathrm{~m}$. Both in the Gryazovetskaya Grove and in the nursery the average diameter of the trunk is $25.1 \mathrm{~cm}$, average crown latitude in the first object -3.7 $\mathrm{m}$, in the second $-4.1 \mathrm{~m}$.

The results of tree health studies are presented in Table 2.

In the distribution of trees by the class of sanitary condition, the largest parts of them are classified as the second class (43, 49 and $47 \%$ ). Tree plantations of class I, II and III are quite viable. The difference from drying and fresh dead wood is that the probability of their death is not determined, it is more random in the near future than expected and natural. There is no reason to expect the trees of these classes to die soon.

Table 2. Sanitary condition of Siberian cedar in studied groves

\begin{tabular}{|l|c|c|c|c|c|c|c|}
\hline \multicolumn{1}{|c|}{ Grove } & \multicolumn{6}{|c|}{$\begin{array}{c}\text { Distribution of trees by } \\
\text { classes of sanitary } \\
\text { condition, \% }\end{array}$} & \multirow{2}{*}{$\begin{array}{c}\text { Weighted } \\
\text { average }\end{array}$} \\
\cline { 2 - 7 } & I & II & III & IV & V & VI & \\
\hline $\begin{array}{l}\text { Chagrinskaya } \\
\text { Grove }\end{array}$ & 27 & 43 & 28 & 2 & - & - & 2.0 \\
\hline $\begin{array}{l}\text { Gryazovetskaya } \\
\text { Grove }\end{array}$ & 18 & 49 & 24 & 7 & 2 & - & 2.3 \\
\hline $\begin{array}{l}\text { Zhernokovo } \\
\text { nursery }\end{array}$ & 27 & 47 & 24 & 2 & - & - & 2.0 \\
\hline
\end{tabular}

The chemical analysis also determined soil acidity, $\mathrm{pH}$ values make 4.98 (Gryazovets), 4.61 (Chagrino) and 4.68 (Gernokovo), weak acid medium, corresponds to podsolic and soddy podzolic soil. The acidity value is suitable for the growth of conifers, vital activity of microorganisms and various biochemical processes.

In the course of the correlation of the actual determined concentration of elements with the maximum permissible concentration, the average values for elements in soil samples under study made from 0.015 MPC (mercury $(\mathrm{Hg})$ ) to $0.84 \mathrm{MPC}$ (arsenic (As)). The results are shown in Table 3.

Table 3. Correlation of actual determined concentration of elements with the maximum permissible concentration.

\begin{tabular}{|c|c|c|c|c|c|}
\hline $\mathrm{n} / \mathrm{n}$ & Indicator & Gryazovetskaya Grove & Chagrinskaya Grove & $\begin{array}{c}\text { Zhernokovo } \\
\text { nursery }\end{array}$ & Average value \\
\hline 1 & Copper $(\mathrm{Cu})$ & $0.20 \mathrm{MPC}$ & $0.17 \mathrm{MPC}$ & $0.20 \mathrm{MPC}$ & $0.19 \mathrm{MPC}$ \\
\hline 2 & Zinc $(\mathrm{Zn})$ & $0.70 \mathrm{MPC}$ & $0.60 \mathrm{MPC}$ & $0.70 \mathrm{MPC}$ & $0.67 \mathrm{MPC}$ \\
\hline 3 & Lead $(\mathrm{Pb})$ & $0.30 \mathrm{MPC}$ & $0.26 \mathrm{MPC}$ & $0.21 \mathrm{MPC}$ & $0.25 \mathrm{MPC}$ \\
\hline 4 & Cadmium $(\mathrm{Cd})$ & $0.16 \mathrm{MPC}$ & $0.13 \mathrm{MPC}$ & $0.09 \mathrm{MPC}$ & $0.13 \mathrm{MPC}$ \\
\hline 5 & Nickel $(\mathrm{Ni})$ & $0.43 \mathrm{MPC}$ & $0.39 \mathrm{MPC}$ & $0.47 \mathrm{MPC}$ & $0.84 \mathrm{MPC}$ \\
\hline 6 & Arsenic $(\mathrm{As})$ & $0.93 \mathrm{MPC}$ & $0.90 \mathrm{MPC}$ & $0.69 \mathrm{MPC}$ & $0.84 \mathrm{MPC}$ \\
\hline 7 & Mercury $(\mathrm{Hg})$ & $0.023 \mathrm{MPC}$ & $0.011 \mathrm{MPC}$ & $0.011 \mathrm{MPC}$ & $0.015 \mathrm{MPC}$ \\
\hline
\end{tabular}


The results of analyses for gross (acid-soluble) content of heavy metals in soil samples of cedar groves and the nursery showed that the numerical values of the studied elements of the I and II classes of toxicity hazard (copper, zinc, lead, cadmium, nickel, chromium, arsenic, mercury) do not exceed the permissible concentrations and fall within normal limits. The identified elements are caused by emissions from stationary sources, highways with exhaust gas.

\section{Conclusion}

The studied cedar groves and the nursery are subject to recreational impact: rest of tourists, collection of cedar cones and needles. As the mensurational description showed, cedar planting successfully continues its growth and fruit bearing. In the distribution of trees by the class of sanitary condition the largest parts of them are classified in the second class, quite viable, there is no reason to expect their drying in the near future.

Soil cover acts serves as one of the main deposit environment where heavy metals are accumulated coming with atmospheric precipitation, leaf debris, dead plants, etc. The danger of these elements is the fact that they are able to accumulate in the cells of living organisms, to be included in ecological chains, to form highly toxic compounds without being biodegradable.

The following conclusions can be drawn as a result of mensurational description, assessment of the sanitary condition of cedar plantations, analysis of microbiological parameters and toxicity of soil samples of cedar groves and nursery of Gryazovets district.

According to statistical indicators (quantitative and qualitative characteristics of cedar plantations), it was revealed that both urban, park planting of Siberian cedar in Gryazovets and outside the urban environment, in Chagrino village and near the Zernkovo village are characterized by good growth. Good lighting of crowns due to thin planting contributed to their development and increased trunk growth in diameter.

According to the results of the sanitary assessment, the largest part of cedar plantations (43\%, 49\% and 47\%) in the objects under study refers to the second class (weakened). Wood plantations of class II are quite viable, probability of their death is not determined, there is no reason to expect drying of trees in the near future.

The content of heavy metals of Class I $(\mathrm{Zn}, \mathrm{Pb}, \mathrm{Cd}$, As, $\mathrm{Hg})$ and Class II (Cu, Ni, Cr) in soil samples justifies no toxic risk of exceeding the maximum permissible concentrations in the groves and the nursery. The average values of elements in the test soil samples range from 0.015 MPC for mercury (minimum value) to 0.84 MPC for arsenic (maximum value).
The assessment of the sanitary condition of the tree stand with a view to timely detection of weakened species, selective sanitary cutting, cleaning of debris, as well as laboratory studies to determine the toxicity of soils affecting the growth and development of cedar plantations, are relevant environmental measures to achieve sustainable development and functioning of Chagrinskaya, Grezovetskaya cedar groves and the nursery near Zhernokovo village.

\section{References}

1. A.P. Glinushkin, M.S. Sokolov, E.Y. Toropova, Phytosanitary and hygienic requirements for healthy soil (Agrus publishing house, Moscow, 2016)

2. S.M. Hamitova, Y.M. Avdeev, N.A. Babich, A.S. Pestovskiy, V.S. Snetilova, A.V. Kozlov, I.P. Uromova, N.N. Koposova, N.A. Pimanova, I.R. Novik, Toxicity assessment of urban soil of Vologda oblast, Int. J. of Pharmaceut. Res., 10(4), 651-654 (2018)

3. Fred Coolborn Akharaiyi, Adeyemi Adegbemisipo Aderoba, Medicinal vegetal use by traditional healers in Ekiti State of Nigeria for diabetes treatment, Int. J. of Pharm. Res. \& Technol., 8, 21-28 (2018)

4. A.V. Kozlov, Assessment of the ecological state of soil cover and water bodies (Minin University, N. Novgorod, 2016)

5. V. Lukashevich, I. Shegelman, A. Vasilyev, M. Lukashevich, Forest certification in Russia: development, current state and problems, Lesnícky časopis, 62(1), 48-55 (2016)

6. Y.P. Popov, Y.M. Avdeev, S.M. Hamitova et al., Monitoring of green spaces' condition using GIStechnologies, Int. J. of Pharmaceut. Res., 10(4), 730-733 (2018)

7. S.S. Mr. Manugula, B., Dr. Veeranna, S. Dr. Patel, GeoSpatial Data Foundation for Dam Sites, Int. J. of Civil Engineer. and Technol., 6(7), 61-68 (2015)

8. I. Pivovarova, Evaluation of spatial uniformity of hydrological characteristics, J. of Engineer. and Appl. Sci., 9(7), 268-272 (2014)

9. Tandel Falguni, More Pratima, Stability Indicating HPLC Method for Simultaneous Estimation of Nicotinamide and Salicylic Acid, Int. J. of Pharm. Res. \& Technol., 8, 43-47 (2018)

10. J. MIttet, Regionalization technique for urban ungauged catchments, 33 (Norvey Univer. of Sci. and Technol., 2017) 